\title{
DATING OF CREMATED BONES
}

\author{
J N Lanting \\ Groningen Institute of Archaeology, University of Groningen, Poststraat 6, 9712 ER Groningen, the Netherlands
}

A T Aerts-Bijma $\bullet \mathrm{J}$ van der Plicht ${ }^{1}$

Centre for Isotope Research, University of Groningen, Nijenborgh 4, 9747 AG Groningen, the Netherlands

ABSTRACT. When dating unburnt bone, bone collagen, the organic fraction of the bone, is used. Collagen does not survive the heat of the cremation pyre, so dating of cremated bone has been considered impossible. Structural carbonate in the mineral fraction of the bone, however, survives the cremation process. We developed a method of dating cremated bone by accelerator mass spectrometry (AMS), using this carbonate fraction. Here we present results for a variety of prehistoric sites and ages, showing a remarkable success rate for this method.

\section{INTRODUCTION}

Since the 1950s, radiocarbon has played an ever-increasing role in archaeology, especially prehistoric archaeology. Collecting charcoal and bone samples for dating during excavations is standard practice and, although less common, systematic dating for research purposes is also becoming more common. The traditional dating techniques require relatively large amounts of sample material. The new accelerator mass spectrometry (AMS)-dating techniques allow the use of very small samples: a single charred grain of wheat, a piece of bone the size of a molar, but, unexpectedly, also the dating of small samples of calcined bone.

Recent studies have emphasized the importance of samples with negligible own-age because the calibration of ${ }^{14} \mathrm{C}$ ages only makes sense when own-ages are absent. Only then can calibrated ${ }^{14} \mathrm{C}$ ages be compared with dendrochronological and/or historic dates. Bone (preferably of terrestrial herbivores) and seeds should therefore be preferred by archaeologists rather than charcoal samples with all their attendant problems which continue to dominate sample selection. Prehistoric human bone is usually a reliable dating material, although occasionally reservoir effects cause ${ }^{14} \mathrm{C}$ dates of human bone be too old, namely when the diet contained large amounts of fish (Lanting and van der Plicht 1998).

The fact that cremated bone was undatable was regarded by many archaeologists as a serious drawback. Cremation burials are regularly associated with pottery and/or with objects of stone, metal, glass, etc. of diagnostic types. At the same time, cremations are often devoid of charcoal, having been hand-picked from the remains of the cremation pyre. But even when charcoal is present, this should not be considered to be the best material for ${ }^{14} \mathrm{C}$ dating, because of the above-mentioned problems. If they could be dated, the calcined bones would be much more reliable dating material.

\section{Structural Carbonate in Bone Mineral}

Bone consists of long chains of proteins (collagen) in which particles of poorly crystallized inorganic material are imbedded. Normally, collagen is used when dating unburnt bone. The inorganic material is primarily a calcium phosphate with an apatite-like structure. A feature of this "bio-apatite" is that it incorporates a certain amount $(0.5-1 \%$ by weight) of carbonate as a substitute for phosphate in the crystal lattice. This so-called structural carbonate has its origin in blood bicarbonate generated by energy production in the cells. It is therefore directly related to the food intake of the person or animal in question. Bone collagen has its origin solely in proteins in the diet and is

${ }^{1}$ Corresponding author. Email: plicht@ phys.rug.nl.

(C) 2001 by the Arizona Board of Regents on behalf of the University of Arizona RadIOCARBON, Vol 43, Nr 2A, 2001, p 249-254

Proceedings of the 17 th International ${ }^{14} \mathrm{C}$ Conference, edited by I Carmi and $\mathrm{E}$ Boaretto 
therefore liable to reservoir effects when these proteins are derived largely from fish and/or shellfish. Structural carbonate has its origin primarily in the carbohydrates and fats in the diet, and in excess protein. Reservoir effects are therefore limited, unless the diet consisted largely of fats and proteins from marine or freshwater food chains.

Structural carbonate is of great interest to palaeodietists who have developed and tested methods of collecting structural carbonate from the bio-apatite and separating it from "absorbed" carbonate in archaeological bones (Lee-Thorp et al. 1989; Lee-Thorp and van der Merwe 1991; Ambrose and Norr 1993). During life, bio-apatite and collagen are replaced in bone at a slow but constant rate. The "own-age" of structural carbonate is therefore limited and similar to that of bone collagen, 1020 years at the most.

Structural carbonate has been used for ${ }^{14} \mathrm{C}$ dating on a very limited scale probably because carbonate in unburnt tooth enamel (which from a chemical point of view is closely related to bio-apatite) produced aberrant dates due to post-depositional changes (Hedges et al. 1995). At the 3rd International Symposium on ${ }^{14} \mathrm{C}$ and Archaeology in Lyon $(6-10$ April, 1998), a group of French scientists presented the results of dating samples of structural carbonate in prehistoric skeletons from the Sahel. These carbonate dates were checked against dates on collagen, charcoal or charred bone and proved to be reliable. Post-depositional changes were not a factor because of the extremely dry climate in the Sahel (Saliège et al. 1998; Person et al. 1998).

\section{Carbonate Dating of Cremated Bone}

After hearing this lecture, the first author realized that it might be possible to date calcined bone from cremation burials using structural carbonate. All previous attempts to date cremated bone had failed because it had been treated as charred bone. Charred bone is heated at relatively low temperatures $\left(200-300{ }^{\circ} \mathrm{C}\right.$ ), contains carbonized fats and proteins and is grey or black inside while calcined bone has been heated at far higher temperatures (above $600^{\circ} \mathrm{C}$ ), contains no carbonized material at all and is white throughout. Some collagen may survive in charred bone, but none survives cremation. However, of great significance is the fact that during cremation, i.e. at temperatures above $600{ }^{\circ} \mathrm{C}$, the bioapatite recrystallizes and larger and better-structured crystals are formed (Shipman et al. 1984). This is one of the reasons why cremated bone survives even in acid soil. During the burning some of the structural carbonate disappears (Stiner et al. 1995) but the first author postulated that it was unlikely that all the structural carbonate would disappear on a prehistoric pyre. The Groningen ${ }^{14} \mathrm{C}$ laboratory was asked to date the structural carbonate from a number of prehistoric cremations of known age.

\section{METHODS}

A $1.5 \%$ sodium hypochlorite solution was used to remove organic material $\left(48 \mathrm{hr}, 20^{\circ} \mathrm{C}\right)$, and $1 \mathrm{M}$ acetic acid to remove the more soluble carbonate ions (such as calcite and adsorbed carbonates), as well as the less crystalline and more soluble fractions of apatite $\left(24 \mathrm{hr}, 20^{\circ} \mathrm{C}\right)$. The apatite yield is about $85 \%$. This pretreated apatite is powdered, and $\mathrm{CO}_{2}$ is produced by reaction with oversaturated phosphoric acid. The reaction time is 8 hours. The $\mathrm{CO}_{2}$ formed is cryogenically trapped in a vacuum extraction system, and purified. Finally, the $\mathrm{CO}_{2}$ is converted into graphite and measured by the Groningen AMS system (Gottdang et al. 1995).

\section{RESULTS}

The results of the extensive testing program for prehistoric cremations with known age are shown in Table 1 (known age based on charcoal dates from the same context) and Table 2 (known historic age). These tests showed that cremated bone does indeed retain sufficient structural carbon- 
Table $1{ }^{14} \mathrm{C}$ ages (BP) of carbonate fractions in calcined bones, compared with ${ }^{14} \mathrm{C}$ ages of charcoal in the same contexts. In a number of cases the charcoal dates are considerably older than the carbonate dates, due to the "old wood" effect. The large difference between cremated bones and charcoal in Oirschot V-21 is due to the lack of pretreatment with alkali of the charcoal samples.

\begin{tabular}{|c|c|c|c|c|}
\hline \multirow{2}{*}{$\frac{\text { Site }}{\text { Damsum }}$} & \multicolumn{2}{|c|}{$\begin{array}{l}\text { Carbonate/calcined bone } \\
\text { (Lab code and date BP) }\end{array}$} & \multicolumn{2}{|c|}{$\begin{array}{l}\text { Charcoal/same context } \\
\text { (Lab code and date BP) }\end{array}$} \\
\hline & GrA-13609 & $1310 \pm 60$ & GrA-14878 & $1320 \pm 40$ \\
\hline Hijker Es & GrA-11259 & $1760 \pm 50$ & GrN-6293 & $1720 \pm 30$ \\
\hline Havelterberg & GrA-13374 & $2120 \pm 40$ & GrN-24992 & $2240 \pm 30$ \\
\hline Laudermarke & GrA-13375 & $2220 \pm 40$ & GrN-24681 & $2290 \pm 30$ \\
\hline Eext 1967 & GrA-11676/7 & $2220 \pm 30$ & GrN-10749 & $2345 \pm 35$ \\
\hline Carthago APM 12.500 & GrA-13589 & $2330 \pm 50$ & GrN-24805 & $2380 \pm 70$ \\
\hline Oudemolen, tum.4 & GrA-14597 & $2390 \pm 50$ & GrN-7398 & $2305 \pm 30$ \\
\hline Wijshagen-De Rieten E & GrA-14281 & $2440 \pm 30$ & IRPA-843/4 & $2308 \pm 42$ \\
\hline Oudemolen & GrA-11263 & $2460 \pm 50$ & GrN-17473 & $2345 \pm 35$ \\
\hline Wapse 58 & GrA-11669/71 & $2535 \pm 30$ & GrN-6868 & $2580 \pm 40$ \\
\hline Wapse 130 & GrA-11672/4 & $2545 \pm 30$ & GrN-6397 & $2390 \pm 35$ \\
\hline Eext 1952 & GrA-11675/13329 & $2725 \pm 30$ & GrN-6750 & $2785 \pm 35$ \\
\hline Buinen HV 14 & GrA-14528 & $2760 \pm 40$ & GrN-6686 & $2940 \pm 55$ \\
\hline Reanascreena & GrA-13394 & $2820 \pm 40$ & GrN-17509 & $2780 \pm 35$ \\
\hline Smeerling & GrA-14991 & $2825 \pm 45$ & GrN-14540 & $2970 \pm 70$ \\
\hline Thourotte & GrA-14509 & $2920 \pm 45$ & GrN-25317 & $2960 \pm 30$ \\
\hline Collinghorst & GrA-13604 & $2950 \pm 50$ & GrN-24683 & $2930 \pm 35$ \\
\hline Anlo-Molenes & GrA-11256 & $2970 \pm 40$ & GrN-13549 & $2945 \pm 35$ \\
\hline Eexterstubben & GrA-13618 & $3260 \pm 50$ & GrN-11905 & $3385 \pm 25$ \\
\hline Strawhall 2 & GrA-14070/827 & $3265 \pm 30$ & OxA-2657 & $3420 \pm 80$ \\
\hline Ballyman & GrA-14291/2 & $3335 \pm 25$ & GrN-10635 & $3370 \pm 50$ \\
\hline Drimnagh & GrA-14607 & $3390 \pm 50$ & OxA-2670 & $3630 \pm 80$ \\
\hline Ballintubbrid & GrA-13393 & $3440 \pm 40$ & GrN-11441 & $3480 \pm 35$ \\
\hline Kilcroagh 3 & GrA-14817 & $3440 \pm 40$ & OxA-2673 (soot) & $3420 \pm 70$ \\
\hline Kilcroagh 2 & GrA-14816 & $3460 \pm 40$ & GrN-15378 & $3510 \pm 35$ \\
\hline Strawhall 3 & GrA-14828 & $3460 \pm 40$ & OxA-2658 & $3440 \pm 70$ \\
\hline Tremoge & GrA-14064 & $3485 \pm 35$ & GrN-11446 & $3570 \pm 45$ \\
\hline Ballyveelish & GrA-14286 & $3520 \pm 30$ & GrN-11657 & $3580 \pm 50$ \\
\hline Grange 10 & GrA-13392 & $3560 \pm 40$ & GrN-9709 & $3480 \pm 35$ \\
\hline Bealick & GrA-14614 & $3590 \pm 50$ & GrN-16790 & $3465 \pm 35$ \\
\hline Eext-Ketenberg & GrA-14564 & $3690 \pm 40$ & GrN-1676 & $3775 \pm 55$ \\
\hline Harristown II & GrA-14756 & $3760 \pm 40$ & GrN-11032 & $3860 \pm 60$ \\
\hline Nijmegen & GrA-14840 & $3850 \pm 40$ & GrN-24978 & $3750 \pm 50$ \\
\hline Dalen & GrA-13617 & $3910 \pm 50$ & GrN-18673 & $3930 \pm 55$ \\
\hline Leer-WH 604 & GrA-13706 & $4170 \pm 50$ & GrN-24682 & $4150 \pm 50$ \\
\hline Angelslo 3 & GrA-13598 & $4220 \pm 50$ & GrN-2370 & $4145 \pm 100$ \\
\hline Oirschot V-21 & GrA-13390 & $8320 \pm 40$ & GrN-14506 & $7790 \pm 130$ \\
\hline Doetinchem & GrA-13387/8 & $10,905 \pm 35$ & GrA-13686 & $10,870 \pm 50$ \\
\hline Kettig & GrA-14762 & $11,210 \pm 60$ & Hd-18123 (bone) & $11,314 \pm 50$ \\
\hline
\end{tabular}

ate for dating by AMS, although in some cases the amount is quite small, not more than $0.1 \%$ by weight. The stable isotope ratio $\delta^{13} \mathrm{C}$ indicated that considerable amounts of carbonate must have burnt out, resulting in a remarkable shift in $\delta^{13} \mathrm{C}$ due to isotopic fractionation during this process, from $-15 \pm 2 \%$ o in unburnt bone to $-24 \pm 3 \%$ o in burnt bone.

This does not influence the possibility of dating cremated bone, however. The tests also showed that sufficient structural carbonate for AMS-dating is present in samples of no more than $1.5 \mathrm{~g}$ of cremated bone. Small fragments, including porous ones, can be used instead of larger fragments of solid calcined bone (Table 3).

In the meantime, more than 200 cremation dates have been produced in Groningen, largely on Dutch, Belgian, northwest German, and Irish material. The results of an Irish dating program 
Table 2 Comparison of ${ }^{14} \mathrm{C}$ ages (BP) of the carbonate fractions in larger pieces resp. in small bits and pieces of the same cremation

\begin{tabular}{lllll}
\hline Site & Historic age & $\begin{array}{l}\text { Expected } \\
{ }^{14} \text { C date BP }\end{array}$ & $\begin{array}{l}\text { Measured } \\
{ }^{14} \text { C date BP }\end{array}$ & Lab code \\
\hline Hoogeloon VIII & 600-650 AD & $1500-1400$ & $1490 \pm 40$ & GrA-13367 \\
Hoogeloon II & 550-600 AD & $1530-1500$ & $1530 \pm 30$ & GrA-13368 \\
Wijster XXIV & 400-500 AD & $1675-1575$ & $1600 \pm 40$ & GrA-13369 \\
Wijster XIX & 350-450 AD & $1700-1560$ & $1700 \pm 40$ & GrA-13370 \\
Besthmen & 200-350 AD & $1850-1700$ & $1780 \pm 40$ & GrA-13372 \\
Carthago 1952.2.12 & 400-146 BC & $2350-2100$ & $2220 \pm 50$ & GrA-13593 \\
Carthago 12.499 & 525-400 BC & $2440-2340$ & $2320 \pm 50$ & GrA-13588 \\
Carthago 12.500 & 525-400 BC & $2440-2340$ & $2330 \pm 50$ & GrA-13589 \\
Carthago 1952.2.2 & 600-250 BC & $2500-2180$ & $2430 \pm 50$ & GrA-13590 \\
Carthago 1952.2.7 & 750-600 BC & $2520-2440$ & $2460 \pm 50$ & GrA-13591 \\
\hline
\end{tabular}

Table $3{ }^{14} \mathrm{C}$ ages (BP) of the carbonate fraction in calcined bones with known historic ages, compared with the expected ${ }^{14} \mathrm{C}$-age ranges

\begin{tabular}{l|lr|rr}
\hline Site & \multicolumn{2}{|c|}{$\begin{array}{c}\text { Large pieces } \\
\text { (Lab code and date BP) }\end{array}$} & \multicolumn{2}{c}{$\begin{array}{c}\text { Small pieces } \\
\text { (Lab code and date BP) }\end{array}$} \\
\hline Eext 1952 & GrA-11675/13329 & $2725 \pm 30$ & GrA-10876 & $2670 \pm 40$ \\
Wapse 58 & GrA-11669 & $2540 \pm 40$ & GrA-11671 & $2530 \pm 40$ \\
Wapse 130 & GrA-11672 & $2580 \pm 40$ & GrA-11674 & $2510 \pm 40$ \\
Eext 1967 & GrA-11676 & $2230 \pm 40$ & GrA-11677 & $2210 \pm 40$ \\
Gasteren 1939:100 & GrA-10877 & $2910 \pm 50$ & GrA-10880 & $2890 \pm 60$ \\
\hline
\end{tabular}

financed by the Heritage Council of Ireland and comprising 46 Bronze Age cremations will be published shortly. A short note with some Irish results, and results of the test program on Dutch cremations appeared recently (Lanting and Brindley 1998). This test program included cremations previously dated on charcoal.

Finally, dates obtained on calcined bone/cremations from the Netherlands, and adjacent Belgium and northwest Germany, are listed in Table 4. This represents a start of a new application in archaeology: the ${ }^{14} \mathrm{C}$ dating of cremated bones.

\section{CONCLUSION}

Cremated bones are exposed to temperatures above $600{ }^{\circ} \mathrm{C}$, where the bone mineral recrystallizes and becomes better structured. During the heating process, most of the structural carbonate disappears, but enough material (carbon content ca. $0.1 \%$ by weight) remains to make AMS dating possible.

We have developed a method for dating cremated bones by AMS, using this carbonate fraction. The results of our extensive testing program are remarkably positive. We have shown that: 1) cremated bone produces reliable ${ }^{14} \mathrm{C}$ dates, 2) cremated bone is very resistant to external influences, due to recrystallization, and 3) no noticeable differences between ${ }^{14} \mathrm{C}$ ages obtained for pieces of solid bones and on small fragments or crumbs of bone are observed. Not more than about $2 \mathrm{~g}$ of cremated bone is required for this method. 
Table $4{ }^{14} \mathrm{C}$ dates for calcined bone/cremations from the Netherlands, Belgium and northwest Germany

\begin{tabular}{|c|c|c|}
\hline Site & Lab code & Date (BP) \\
\hline \multicolumn{3}{|c|}{ Late Palaeolithic Federmesser site near Doetinchem } \\
\hline Calcined bone from hearth & GrA-13387 & $10,880 \pm 50$ \\
\hline Calcined bone from dump zone & GrA-13388 & $10,930 \pm 50$ \\
\hline Charcoal in settlement layer & GrA-13686 & $10,870 \pm 50$ \\
\hline \multicolumn{3}{|c|}{ Cremation burials of the late Havelte phase of the Funnel Beaker Culture } \\
\hline Angelslo grave 1 & GrA-13705 & $4200 \pm 50$ \\
\hline Angelslo grave 3 & GrA-13598 & $4220 \pm 50$ \\
\hline Angelslo grave 5 & GrA-13599 & $4130 \pm 50$ \\
\hline Leer WH 578 & GrA-14093 & $4205 \pm 40$ \\
\hline Leer WH 581 & GrA-14088 & $4270 \pm 40$ \\
\hline Leer WH 585 & GrA-14089 & $4190 \pm 35$ \\
\hline Leer WH 600 & GrA-14168 & $4170 \pm 40$ \\
\hline Leer WH 604 & GrA-13706 & $4170 \pm 50$ \\
\hline \multicolumn{3}{|c|}{ Cremation burials with bell beakers of Veluvian type in the Lower Rhine area } \\
\hline Meerlo & GrA-14066 & $3840 \pm 35$ \\
\hline Hoog-Buurlo & GrA-14067 & $3830 \pm 35$ \\
\hline Veen, Kr. Moers & GrA-14080 & $3810 \pm 40$ \\
\hline Nijmegen & GrA-14840 & $3850 \pm 40$ \\
\hline \multicolumn{3}{|c|}{ Cremation in Middle Bronze Age urns of Drakenstein type } \\
\hline Neer & GrA-14529 & $3340 \pm 40$ \\
\hline Poppel & GrA-14285 & $3320 \pm 30$ \\
\hline \multicolumn{3}{|c|}{ Cremation burial with bronze sword of Wohlde type } \\
\hline Garderen-Bergsham no. 25 & GrA-13707 & $3320 \pm 50$ \\
\hline \multicolumn{3}{|c|}{ Keyhole shaped ditches in Late Bronze Age urn fields } \\
\hline Erica-Hankenberg & GrA-14527 & $2840 \pm 40$ \\
\hline Buinen-HV 14 & GrA-14528 & $2760 \pm 40$ \\
\hline Smeerling & GrA-14991 & $2825 \pm 45$ \\
\hline \multicolumn{3}{|l|}{ Harpsted-type urns of the Early Iron Age } \\
\hline WapseW70 & GrA-11669/71 & $2535 \pm 30$ \\
\hline Wapse W152 & GrA-11672/74 & $2545 \pm 30$ \\
\hline \multicolumn{3}{|c|}{ Rich graves of the middle Iron Age, with situlae $(C, E)$ and ribbed bucket $(H)$} \\
\hline Wijshagen-De Rieten C & GrA-14279 & $2420 \pm 30$ \\
\hline Wijshagen-De Rieten E & GrA-14281 & $2440 \pm 30$ \\
\hline Wijshagen-De Rieten $\mathrm{H}$ & GrA-14284 & $2430 \pm 30$ \\
\hline \multicolumn{3}{|l|}{ Cremation burial in Anglo-Saxon pottery } \\
\hline Wijster grave XXIV & GrA-13369 & $1600 \pm 40$ \\
\hline \multicolumn{3}{|c|}{ Cremation burials with Frankish Knickwand pottery } \\
\hline Hoogeloon-Broekeneind grave II & GrA-13368 & $1530 \pm 30$ \\
\hline Hoogeloon-Broekeneind grave VIII & GrA-13367 & $1490 \pm 40$ \\
\hline
\end{tabular}




\section{REFERENCES}

Ambrose SE, Norr L. 1993. Experimental evidence for the relationship of the carbon isotope ratios of whole diet and dietary protein to those of bone collagen and carbonate. In: Lambert JB, Grupe G, editors. Prehistoric human bone. Archaeology at the molecular level. Berlin: Springer Verlag. p 1-37.

Gottdang A, Mous DJW, van der Plicht J. 1995. The HVEE ${ }^{14} \mathrm{C}$ system at Groningen. Radiocarbon 37(2): 649-56.

Hedges REM, Thorp JA, Tuross NC. 1995. Is toothenamel carbonate a suitable material for radiocarbon dating? Radiocarbon 37(2):285-90.

Lanting JN, Brindley AL. 1998. Dating cremated bone: the dawn of a new era. Journal of Irish Archaeology 9: $1-7$.

Lanting JN, van der Plicht J. 1998. Reservoir effects and apparent ${ }^{14} \mathrm{C}$ ages. Journal of Irish Archaeology 9: $151-65$.

Lee-Thorp JA, Sealy JC, van der Merwe NJ. 1989. Stable carbon isotope ratio differences between bone collagen and bone apatite, and their relationship to diet. Journal of Archeological Science 16:585-99.

Lee-Thorp JA, van der Merwe NJ. 1991. Aspects of the chemistry of modern and fossil biological apatites. Journal of Archeological Science 18:43-354.

Person A, Saliège J-F, Gérard, Paris F. 1998. Utilisation d'un indice caractéristique de la diagenèsede la fraction minéral d'ossements archéologiques en milieu désertique pour discuter de la fiabilité de ces matériaux comme support de datation par le radiocarbone, application à deux nécropoles néolithique de l'Aïr (Niger). Pré-actes du 3ème Congrès International ${ }^{14} \mathrm{C}$ et Archéologie, Lyon 1998. p 77-8.

Saliège J-F, Person A, Paris F. 1998. Datation du carbonate-hydroxylapatite d'ossements Holocènes du Sahel (Mali, Mauritanie, Niger). Pré-actes du 3ème Congrès International ${ }^{14}$ C et Archéologie, Lyon 1998. p 172-3.

Shipman P, Foster GF, Schoeninger M. 1984. Burnt bones and teeth: an experimental study of colour, morphology, crystal structure and shrinkage. Journal of Archaeological Science 11:307-25.

Stiner MC, Kuhn SL, Weiner S, Bar-Yosef O. 1995. Differential burning, recrystallization and fragmentation of archaeological bone. Journal of Archaeological Science 22:223-327. 